\title{
Precipitation Behavior of Boron in High Strength Steel*
}

\author{
By Seiichi WATANABE** and Hiroo OHTANI**
}

\section{Synopsis}

The hardenability of boron steel is affected by the precipitation behavior of B. Precipitates in the B containing steel were studied by extraction replica technique at the successive manufacturing steps from hot-rolling to heat treatment.

When steels are hot-rolled after heating at $1300^{\circ} \mathrm{C}$ for $1 \mathrm{~h}$, changes of $\mathrm{B}$ precipitates with the cooling rate after hot-rolling are as follows:

(1) When steels are water-quenched (cooling rate of $90000^{\circ} \mathrm{C} / \mathrm{min}$ ) after hot-rolling, no precipitates can be observed on $\gamma$ grain boundaries.

(2) When steels are air-cooled (cooling rate of $300^{\circ} \mathrm{C} / \mathrm{min}$ ) after hot rolling, BN precipitates on $\gamma$ grain boundary region.

(3) When steels are furnace-cooled (cooling rate of $0.67^{\circ} \mathrm{C} / \mathrm{min}$ ) after hot-rolling, $\mathrm{AlN}$ grows radially from $\mathrm{BN}$ which has precipitated before the nucleation of $\mathrm{AlN}$. $\mathrm{AlN}$ formed on $\mathrm{BN}$ during furnace-cooling is dendritic.

By reheating at a rate of $15^{\circ} \mathrm{C} / \mathrm{min}$ a specimen which has been waterquenched after hot-rolling (above-mentioned as (1)), the following B precipitates appear depending upon the temperature range:

(1) Below $880^{\circ} \mathrm{C}, \mathrm{M}_{23}(\mathrm{CB})_{6}$ precipitates and coagulates on prior grain boundaries.

(2) Above $900^{\circ} \mathrm{C}$ and below about $1000^{\circ} \mathrm{C}, \mathrm{BN}$ appears on prior grain boundary region which has been previously occupied by $\mathrm{M}_{23}(\mathrm{C}, \mathrm{B})_{6}$. $\mathrm{M}_{23}(\mathrm{G}, \mathrm{B})_{6}$ is no longer observed at this stage.

(3) Heating at around $1000^{\circ} \mathrm{C}$, AlN which is not dendritic but acicular grows radially from $\mathrm{BN}$. The size of $\mathrm{BN}$ diminishes with growth of acicular AIN.

The formation of $\mathrm{AlN}$ on $\mathrm{BN}$ is interpreted as a transit from the nonequilibrium to equilibrium state in $\mathrm{Al}-\mathrm{B}-\mathrm{N}$ system in steels.

According to Pease, BN (hexagonal close packed) has the same crystal structure as that of graphite. Because $\mathrm{BN}$ in steels was revealed to have spherulite morphology such as spherical graphite, it is considered that [00.1] axes of $\mathrm{BN}$ are arranged in radial fashion and (00.1) planes are perpendicular to them, by an analogy to the crystal arrangement of spherical graphite. As the growth direction of $\mathrm{AlN} i s[0.01]_{\mathrm{A} 1 \mathrm{~N}}$, it is considered that an orientation relationship of $(00.1)_{\mathrm{BN}} / /(00.1)_{\mathrm{A} 1 \mathrm{~N}}$ is satisfied when $\mathrm{AlN}$ grows on $\mathrm{BN}$.

\section{Introduction}

The use of B treated steel is expected to increase from the view point of saving resources but much care is necessary to manufacture B added steels. For example, there is a phenomenon that the hardenability of $B$ treated steels decreases by over-heating. ${ }^{1-5)}$ Many papers have been reported concerning with this phenomenon and at present it appears difficult even to reproduce experimentally the same results.
Authors deduced that the phenomenon depends on the precipitation behavior of $B$ precipitates such as $\mathrm{BN}, \mathrm{M}_{23}(\mathrm{C}, \mathrm{B})_{6}$, etc., during the manufacturing processes. ${ }^{6,7)}$ This paper deals with the different kinds of $\mathrm{B}$ precipitates which change their state depending on the heating temperature before rolling, cooling rate after rolling and quenching temperature during heat treatment of $\mathrm{Al}-\mathrm{B}$ treated steels. This paper also discusses microstructures of $\mathrm{BN}$, as few papers have reported about the microstructure of $\mathrm{BN}$ in steels.

\section{Experimental Procedures}

The chemical compositions of materials are shown in Table 1. Steel X is Cu-Ni-Cr-Mo-V-0.0025\%B$0.0107 \% \mathrm{~N} 80 \mathrm{~kg} / \mathrm{mm}^{2}$ grade high tensile strength steel and steel $\mathrm{Y}$ is $0.0096 \% \mathrm{~B}-0.0326 \% \mathrm{~N}-\mathrm{Fe}$. Steel $\mathrm{X}$ was heated at 1300 or $1000^{\circ} \mathrm{C}$ for $1 \mathrm{~h}$ and reduced its thickness by hot-rolling from 30 to $5 \mathrm{~mm}$ and afterwards cooled at a cooling rate of about $90000^{\circ} \mathrm{C} / \mathrm{min}$ (water-quenched), $300^{\circ} \mathrm{C} / \mathrm{min}$ (aircooled) or $0.67^{\circ} \mathrm{C} / \mathrm{min}$ (furnace-cooled). The waterquenched specimens were reheated at a rate of 15 ${ }^{\circ} \mathrm{C} / \mathrm{min}$ and quenched immediately after reaching determined temperatures. Steel $\mathrm{Y}$ was forged after heating at $1300^{\circ} \mathrm{C}$ for $1 \mathrm{~h}$ and air-cooled. Replicas extracted from these specimens were observed by the electron microscope with an accelerating voltage 100 $\mathrm{kV}$.

\section{Results}

\section{Boron Precipitates during Hot Rolling}

Replicated microstructures extracted from the specimens which were hot-rolled after heating at $1300^{\circ} \mathrm{C}$ for $1 \mathrm{~h}$ and air-cooled from $900^{\circ} \mathrm{C}$ after rolling are shown in Photo. 1. Precipitates in dotted line are identified as $\mathrm{BN}$ from the interplaner intervals calculated from diameters of electron diffraction rings. ${ }^{8)}$ It is known that BN has several crystal structures in atmosphere. Interplaner intervals measured from Photo. 1 show that $\mathrm{BN}$ in steel agrees with the hexagonal one found by Pease $^{8)}$ who made samples by

Table 1. Chemical compositions of materials. (wt \%)

\begin{tabular}{c|ccccccccccccc}
\hline Steel & $\mathrm{C}$ & $\mathrm{Si}$ & $\mathrm{Mn}$ & $\mathrm{P}$ & $\mathrm{S}$ & $\mathrm{Gu}$ & $\mathrm{Ni}$ & $\mathrm{Cr}$ & $\mathrm{Mo}$ & $\mathrm{V}$ & Sol. Al & Total B & $\mathrm{N}$ \\
\hline $\mathrm{X}$ & 0.11 & 0.29 & 0.85 & 0.009 & 0.008 & 0.25 & 1.02 & 0.39 & 0.46 & 0.03 & 0.074 & 0.0025 & 0.0107 \\
$\mathrm{n}$ & 0.004 & $<0.01$ & $>0.01$ & 0.002 & 0.005 & 0.02 & $<0.01$ & $<0.01$ & $<0.01$ & $<0.01$ & $<0.001$ & 0.0096 & 0.0326 \\
\hline
\end{tabular}

* Originally published in Tetsu-to-Hagané, 62 (1976), 1851, in Japanese. English version received December 22, 1981. (C) 1983 ISIJ

** Central Research Laboratories, Sumitomo Metal Industries, Ltd., Nishinagasu-hondori, Amagasaki 660. 

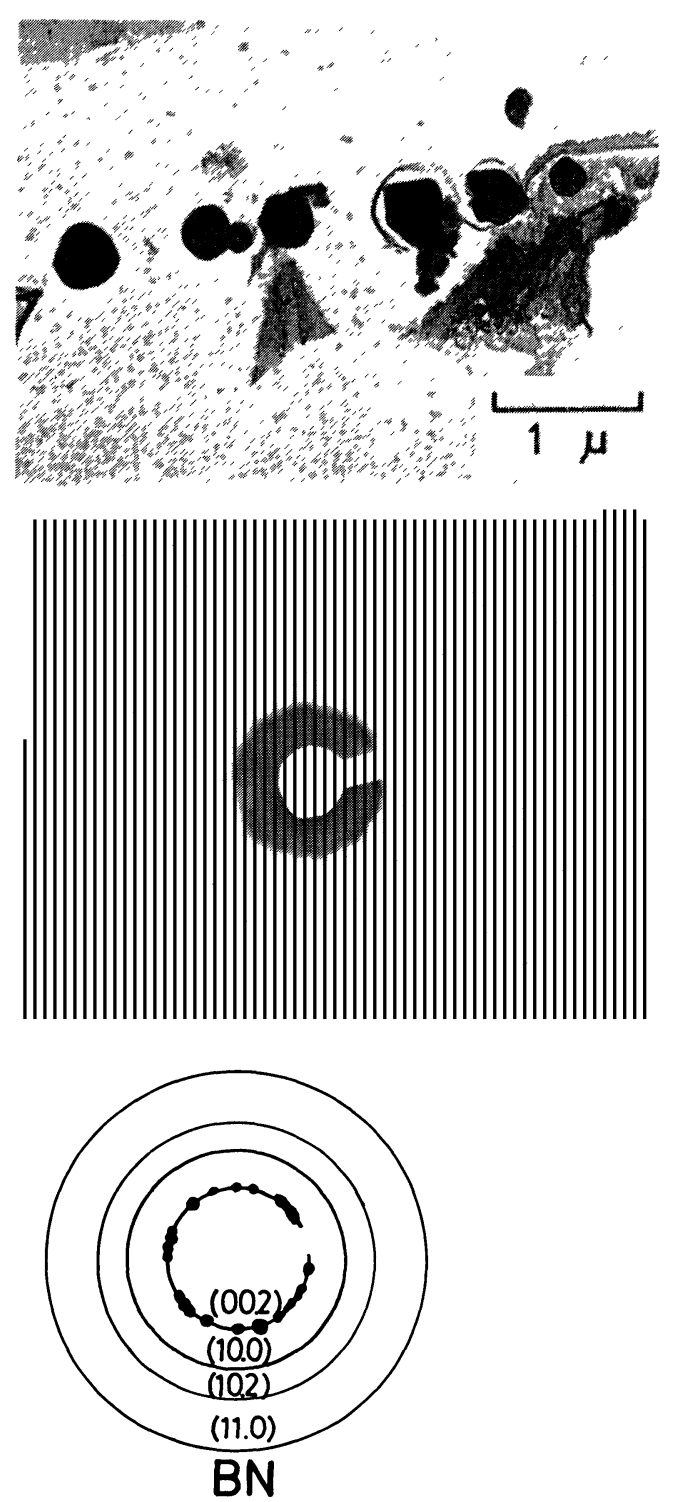

Photo. 1. Precipitates in steel $\mathrm{X}$ air-cooled from $800^{\circ} \mathrm{C}$ after heating at $1300^{\circ} \mathrm{C}$ for $1 \mathrm{~h}$ and hot-rolling.

Diffraction rings identify the precipitates as BN.

reacting $\mathrm{B}$ and $\mathrm{N}_{2}$ gases directly at high temperatures. Throughout the present experiment diffraction patterns of single crystal were not obtained but showed only diffraction rings characteristic of polycrystalline structure.

Replicated microstructure extracted from steel $\mathrm{X}$ which is furnace-cooled from $900^{\circ} \mathrm{C}$ after heating at $1300{ }^{\circ} \mathrm{C}$ and hot-rolled is shown in Photo. 2. There observed many complicated precipitates which are composed of globular precipitates at the core and dendritic ones radially grown from the core. Electron diffraction patterns resulted from the vicinity of the core (Photo. 3), are the superposed ones which are composed of AlN spots and BN rings. Because electron diffraction patterns resulted from radially grown parts indicate only AlN, it is concluded that AlN grows radially on the core of BN. The morphology of AlN which precipitates and grows during furnace cooling is dendritic. ${ }^{9,10)}$ When steel $\mathrm{X}$ is hot-rolled and then cooled after $\mathrm{Al}, \mathrm{B}$ and $\mathrm{N}$ dissolved

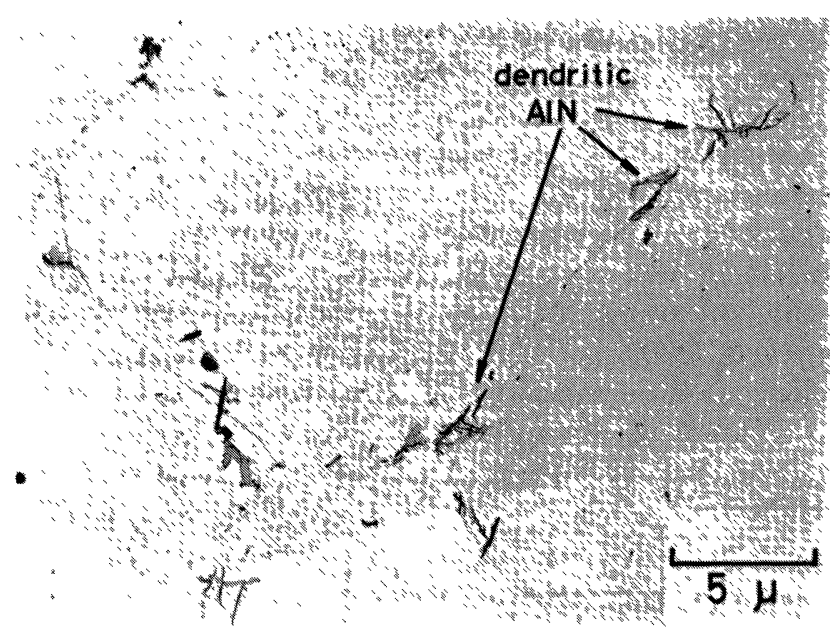

Photo. 2. Precipitates in steel $\mathrm{X}$ furnace-cooled from $800^{\circ} \mathrm{C}$ after heating at $1300^{\circ} \mathrm{C}$ for $1 \mathrm{~h}$ and hot-rolling.
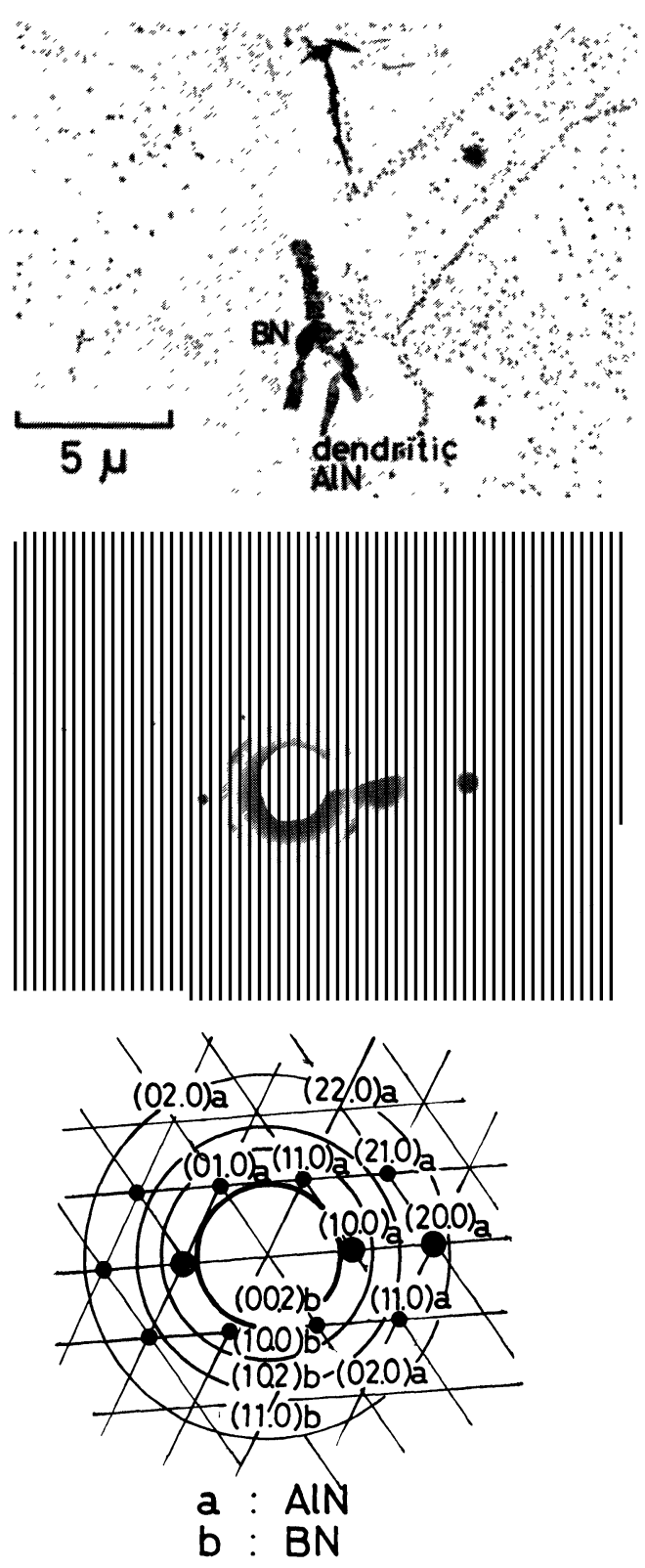

Photo. 3. Precipitates in steel $\mathrm{X}$ furnace-cooled from $800^{\circ} \mathrm{C}$ after heating at $1300^{\circ} \mathrm{C}$ for $1 \mathrm{~h}$ and hot-rolling. AlN grows radially on BN. AlN observed in Photos. 2 and 3 is dendritic. 
into solid solution by heating at $1300^{\circ} \mathrm{C}$, the state occurs in which $\mathrm{BN}$ precipitates on austenite grain boundaries although $\mathrm{Al}$ is in solid solution. During cooling $\mathrm{B}$ and $\mathrm{N}$ atoms segregate to austenite grain boundaries due to their high diffusion velocity, so that concentration of $\mathrm{B}$ and $\mathrm{N}$ atoms at grain boundaries increases and exceeds the solubility product while $\mathrm{Al}$ atoms distribute homogeneously and do not prevent $\mathrm{BN}$ to precipitate. As mentioned later, the effect of $\mathrm{B}$ on the hardenability almost disappears at this stage. It is supposed that the stage corresponds to the non-equilibrium state of $\mathrm{Al}-\mathrm{B}-\mathrm{N}-\mathrm{Fe}$ system. Habu et al. showed, ${ }^{5)}$ by calculating $\mathrm{B}$ content in solid solution in the equilibrium state of $\mathrm{Al}-\mathrm{B}-\mathrm{N}-\mathrm{Fe}$ system, that $\mathrm{Al}$ protects all of $\mathrm{B}$ from precipitating as $\mathrm{BN}$ by fixing $\mathrm{N}$ as $\mathrm{AlN}$, so that $\mathrm{B}$ in solid solution necessary for increasing hardenability is obtained.

If the cooling rate is very slow like furnace-cooling, $\mathrm{Al}$ atoms migrate into grain boundaries and precipitate as AlN on the surface of BN particles. Al-B-NFe system approaches the equilibrium state at this stage. There observed no evident B precipitate in the samples which are water-quenched after heated at $1300^{\circ} \mathrm{C} \times 1 \mathrm{~h}$ and hot-rolled. ${ }^{11)}$

Photograph 4 shows the extraction replicated microstructure of steel $\mathrm{X}$ which is water-quenched after heating at $1000^{\circ} \mathrm{G}$ for $1 \mathrm{~h}$ and hot-rolled. Many rectangular $\mathrm{AlN}$ indicate that $\mathrm{AlN}$ scarcely dissolves into solid solution at $1000^{\circ} \mathrm{C}$. ${ }^{12}$ )

\section{Boron Precipitates during Heat Treatment}

Photograph 5 shows replicated microstructure of steel $\mathrm{X}$ which was heated at a rate of $15^{\circ} \mathrm{C} / \mathrm{min}$ and quenched immediately after reaching at $880^{\circ} \mathrm{C}$. Preceding to the heat treatment, steel $\mathrm{X}$ was water quenched from finishing temperature after heating at $1300{ }^{\circ} \mathrm{C}$ and hot-rolled.

There observed precipitates on prior austenite grain boundaries identified as $\mathrm{M}_{23}(\mathrm{C}, \mathrm{B})_{6} \cdot{ }^{13,14}$ Cementite within the grains dissolves into solid solution and martensite forms by water quenching.

It is supposed that $\mathrm{M}_{23}(\mathrm{C}, \mathrm{B})_{6}$ precipitates during heating below $A c_{1}$ and remains over $A c_{3}$ temperature. $A c_{3}$ temperature of steel $\mathrm{X}$ is about $850^{\circ} \mathrm{C}$. $\mathrm{BN}$ is not observed in Photo. 5. The replicated microstructure of steel $\mathrm{X}$ which is heated up to $930^{\circ} \mathrm{C}$ and quenched is shown in Photo. 6. Precipitates on prior austenite grain boundaries are identified as $\mathrm{BN}$ and $\mathrm{M}_{23}(\mathrm{C}, \mathrm{B})_{6}$ is no longer observed. When the specimen is reheated in which $\mathrm{B}, \mathrm{N}, \mathrm{C}$ and $\mathrm{Al}$ atoms are in solid solution, the precipitate that forms on prior austenite grain boundaries below $A c_{1}$ is not $\mathrm{BN}$ but $\mathrm{M}_{23}(\mathrm{C}, \mathrm{B})_{6} . \quad \mathrm{M}_{23}(\mathrm{C}, \mathrm{B})_{6}$ does not dissolve into solid solution even after completely austenitized, but heating at higher than $900^{\circ} \mathrm{C}, \mathrm{M}_{23}(\mathrm{C}, \mathrm{B})_{6}$ dissolves and free $\mathrm{B}$ atoms combine with remaining free $\mathrm{N}$ and precipitate as BN.

Heated at $1000{ }^{\circ} \mathrm{G}, \mathrm{AlN}$ precipitates and grows radially on $\mathrm{BN}$ particles as shown in Photo. 7. The morphology of AlN formed on $\mathrm{BN}$ during reheating is not dendritic but acicular.

The growth direction of AlN is determined as iden-

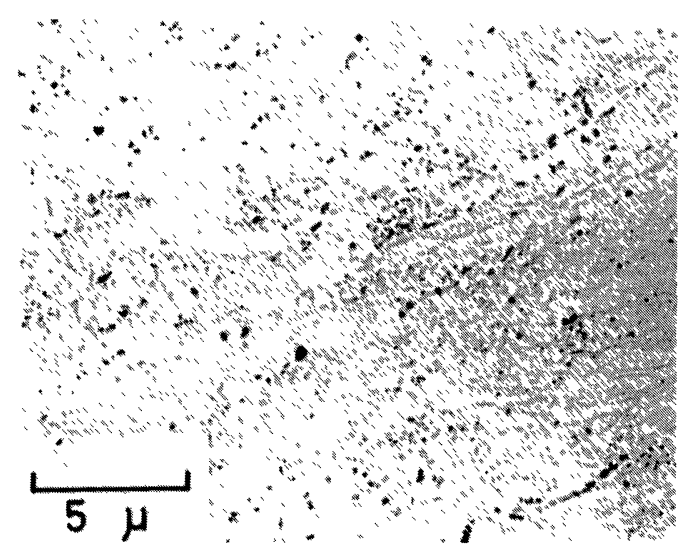

Photo. 4. Precipitates in steel $\mathrm{X}$ water-quenched from $800^{\circ} \mathrm{G}$ after heating at $1000^{\circ} \mathrm{C}$ for $1 \mathrm{~h}$ and hot-rolling.
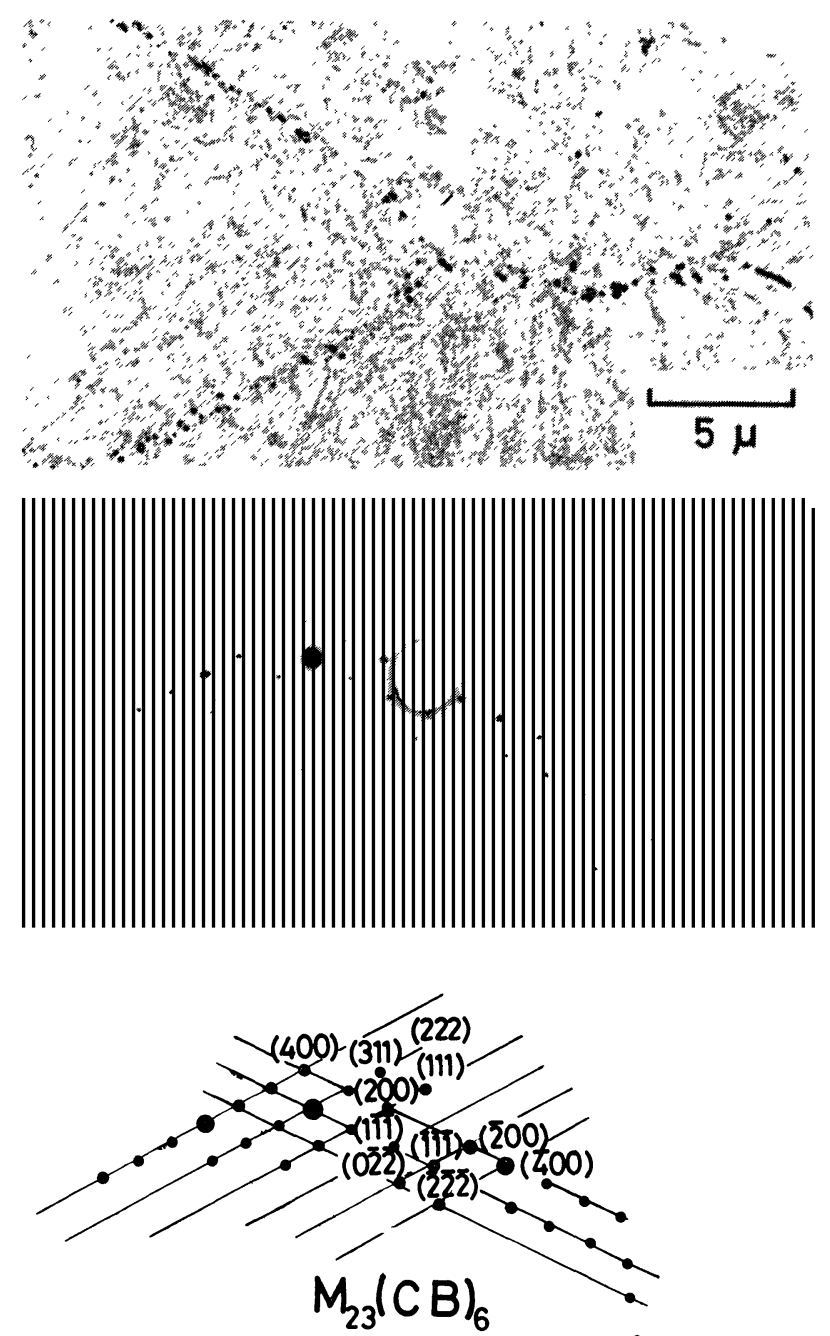

Photo. 5. Precipitates in steel $\mathrm{X}$ reheated at $800{ }^{\circ} \mathrm{G}$ after heating at $1300^{\circ} \mathrm{C}$ for $1 \mathrm{~h}$, hot-rolling and water-quenching.

$\mathrm{M}_{23}(\mathrm{CB})_{6}$ forms on prior $\gamma$ grain boundary region.

tical with $[00.1]_{\mathrm{A} 1 \mathrm{~N}}$ after compensating the rotating angle of intermediate lens of electron microscope.

The precipitation of AIN on the surface of BN during reheating is the necessary stage for $\mathrm{Al}-\mathrm{B}-\mathrm{N}-\mathrm{Fe}$ system to approach the equilibrium state after hotrolling as with the case of slow cooling. 


\section{The Microstructure of $\mathrm{BN}$}

Photograph 8 shows $\mathrm{BN}$ in steel Y. It shows that spherical $\mathrm{BN}$ is composed of many cone-like crystals radially grown from a common center at which all of

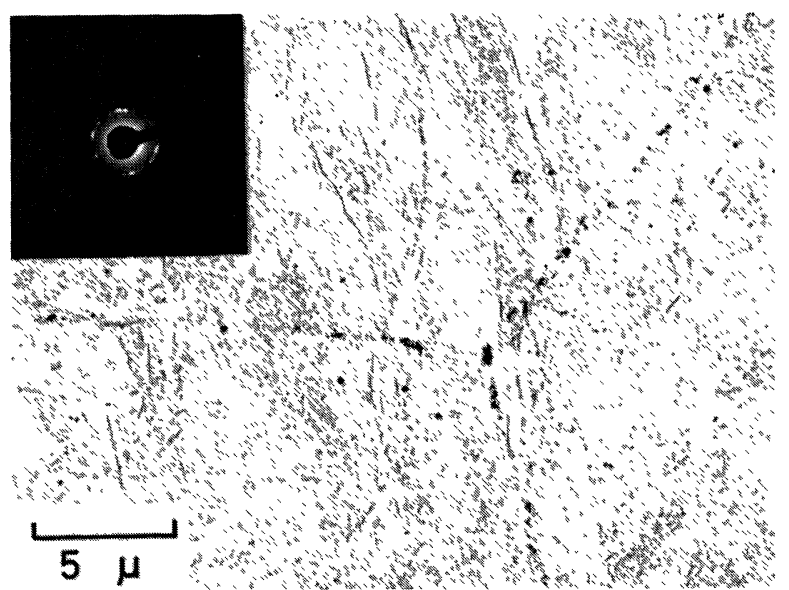

Photo. 6. Precipitates in steel $\mathrm{X}$ reheated at $930{ }^{\circ} \mathrm{C}$ after heating at $1300{ }^{\circ} \mathrm{C}$ for $1 \mathrm{~h}$, hot-rolling and water-quenching.

$\mathrm{BN}$ forms on prior $\gamma$ grain boundary region.

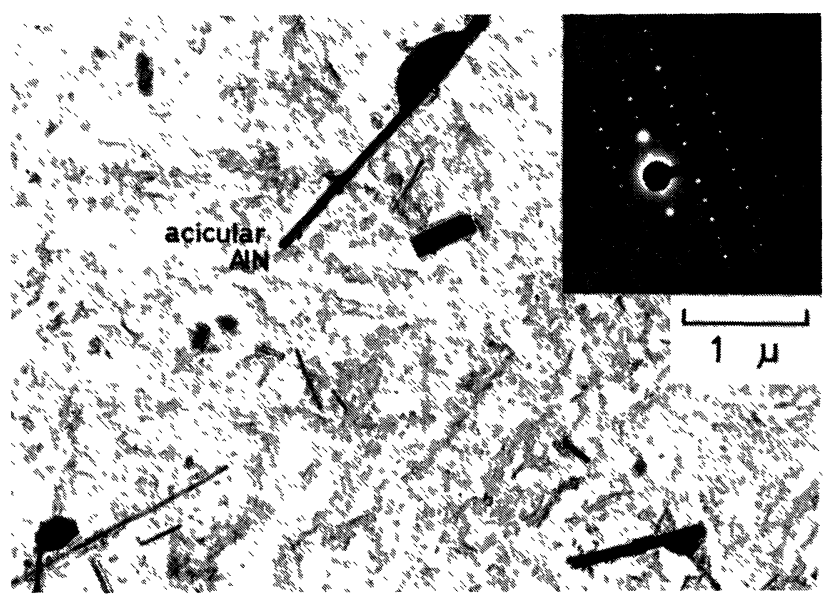

Photo. 7. Precipitates in steel $\mathrm{X}$ reheated at $1000^{\circ} \mathrm{C}$ after heating at $1300^{\circ} \mathrm{C}$ for $1 \mathrm{~h}$, hot-rolling and waterquenching.

Acicular AlN grows on BN.

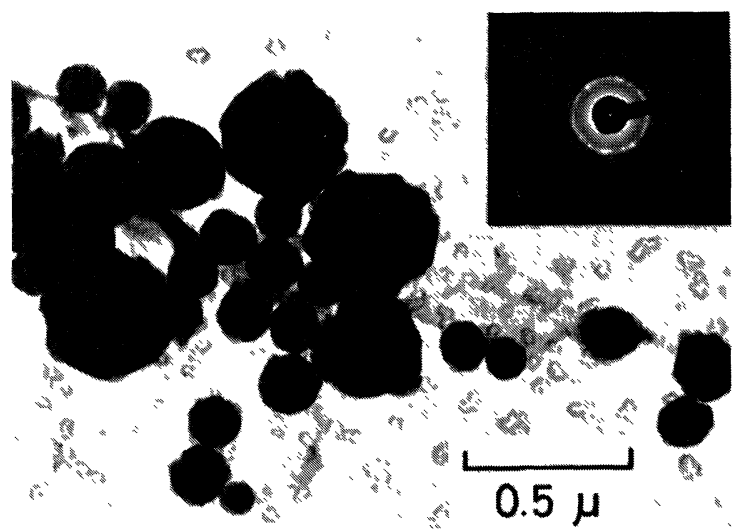

Photo. 8. BN in steel $\mathrm{Y}$

$\mathrm{BN}$ has spherulite structure such as spherical graphite in iron. cone tops are located. This is similar to that of spherical graphite.

Owing to this structure, diffraction pattern of $\mathrm{BN}$ results in the continuous rings characteristic of a polycrystal.

\section{Discussion}

Boron precipitates observed on each stage in the experiment are represented schematically in Fig. 1. Boron precipitates in steel $\mathrm{X}$ are $\mathrm{BN}$ and $\mathrm{M}_{23}(\mathrm{CB})_{6}$. Hexagonal close packed $\mathrm{BN}$ found by $\mathrm{Pease}^{8)}$ in which $\mathrm{B}$ and $\mathrm{N}$ atoms form two dimensional nets by covalent bonding and each layer of net combines with others by Van der Waals force similar to graphite. Photograph 8 shows that $\mathrm{BN}$ in steel has spherulite morphology such as spherical graphite. According to Morrough and Williams, ${ }^{15}$ ) in spherical graphite, $\mathrm{C}$ axes are arranged in radial fashion and (00.1) planes are perpendicular to them. It is supposed by analogy to spherical graphite that $\mathrm{BN}$ in steel also has similar crystal orientation arrangement. As shown in Fig. 2, it is thought that [00.1] axes of $\mathrm{BN}$ are arranged in radial fashion and $(00.1)_{B N}$ planes are perpendicular to them. As the growth direction of AlN is identical with $[00.1]_{A 1 N}$, it is inferred that the orientation relationship $(00.1)_{\mathrm{BN}} / /(00.1)_{\mathrm{AlN}}$ is satisfied locally on the surface of BN. The other precipitate $\mathrm{M}_{23}(\mathrm{CB})_{6}$ forms below $A c_{1}$ during reheating after quenching at so high a cooling rate that $\mathrm{B}, \mathrm{N}$ and $\mathrm{C}$ atoms remain in solid solution. On this stage $\mathrm{BN}$ is not observed. It is impossible to estimate which is more stable because formation free energies of $\mathrm{BN}$ and $\mathrm{M}_{23}(\mathrm{CB})_{6}$ are not yet obtained below $A c_{1}$. Over $A c_{3}$ temperature, there are the experimental value of $\mathrm{BN}$ by Fountain and Chipman ${ }^{16)}$ and the calculated one of $\mathrm{M}_{23}(\mathrm{CB})_{6}$ by Hasebe and Nishizawa. ${ }^{17)}$ Comparing with the two, $\mathrm{BN}$ is more stable. So above $A c_{3}$ the estimation accords with this experiment.

In discussing the precipitation behavior of $\mathrm{B}$ below $A c_{1}$, it is necessary to take kinematical consideration into account besides the thermodynamical stability in equilibrium state. That is, for the sake of the precipitation of $\mathrm{M}_{23}(\mathrm{CB})_{6}$, substitutional atoms (mainly Fe atoms) change their place only a very little distance to fit for the atomic arrangement of $\mathrm{M}_{23}(\mathrm{CB})_{6}$. However, as it is supposed that BN contains no or little $\mathrm{Fe}$ atoms, it is necessary for $\mathrm{Fe}$ atom to diffuse away a long distance to leave the space for the precipitation and growth of BN. On this account, it is thought in the lower temperature range $M_{23}(C B)_{6}$ predominantly precipitates and grows.

It is well known that $\mathrm{B}$ added steel decreases its hardenability after over-heating above $1150^{\circ} \mathrm{C} . .^{5-7)}$ Precipitation behavior of $\mathrm{B}$ atoms in this experiment has a good correspondence with the phenomenon of hardenability change. That is, the state that $\mathrm{B}$ precipitates remain on prior austenite grain boundaries corresponds to that in which $\mathrm{B}$ factor for hardenability decreases to almost 1.0 (no effect). Figure $3^{7)}$ shows the influence of the 1st step quenching temperature $T$ on the hardenability of the following 2 nd step quenching of $\mathrm{B}$ added steel which was precedingly 


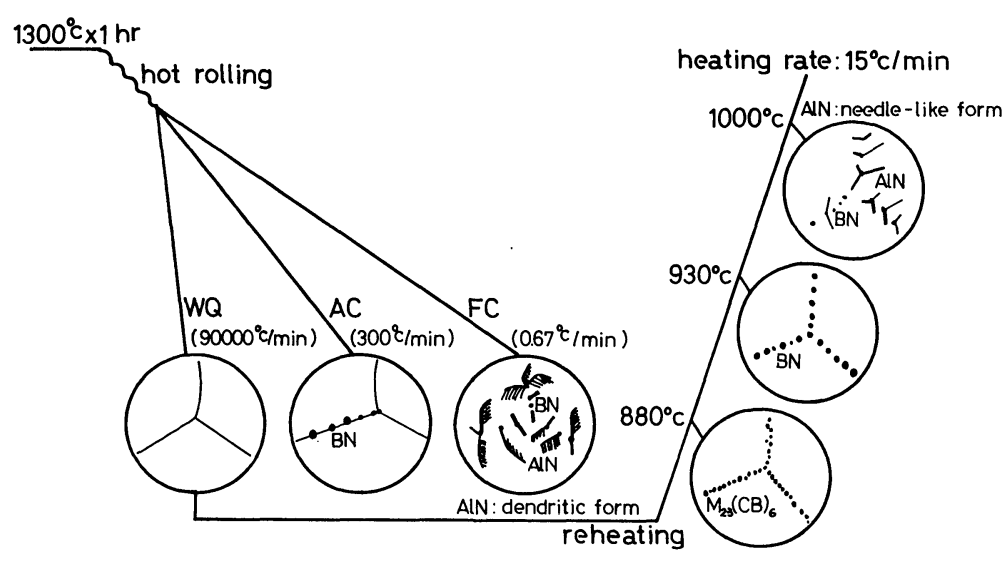

Fig. 1.

Schematic illustration of precipitation behavior of $\mathrm{B}$ in the manufacturing process.

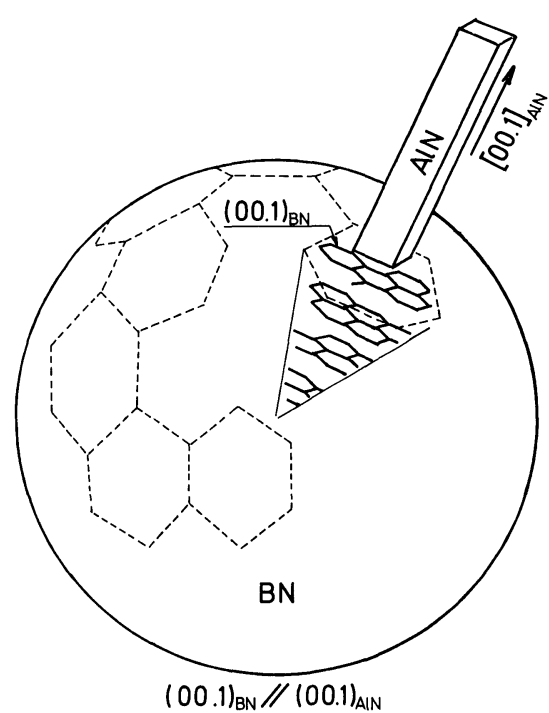

Fig. 2. Schematic representation of spherical BN.

The orientation relationship $(00.1)_{\mathrm{BN}} / /(00.1)_{\mathrm{AlN}}$ exists between $\mathrm{BN}$ and $\mathrm{AlN}$ when AlN grows radially on $\mathrm{BN}$.

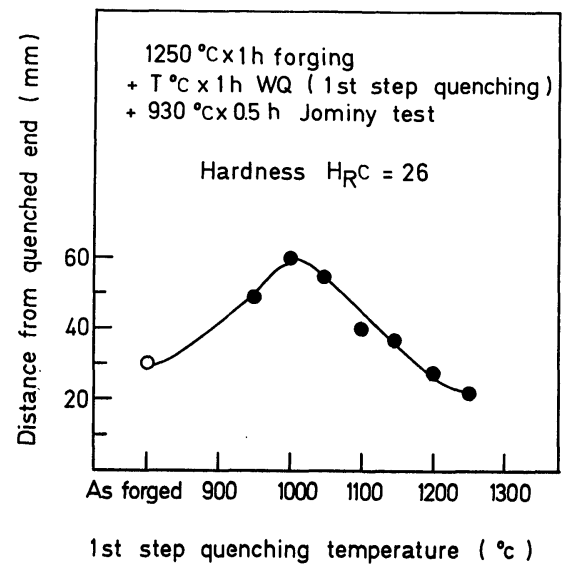

Fig. 3. Influence of 1 st step quenching temperature $T$ upon the following hardenability.

The hardenability is evaluated by the distance from quenched end at which hardness is Rockwell C 26.

over-heated at $1200^{\circ} \mathrm{C}$ before forging. In Fig. 3 hardenability is represented by the location of $H_{R} C=$ 26 measured from the quenched end of Jominy test. In the as forged state the effect of $B$ is not fully obtained. This stage corresponds to the state in which BN forms as shown in Photo. 1 or Photo. 6. The hardenability on the following step of quenching is recovered after reheating at $1000^{\circ} \mathrm{C}$ for $1 \mathrm{~h}$. This state corresponds to that in which AlN precipitates on the surface of $\mathrm{BN}$ and free $\mathrm{B}$ increases, owing to the reaction of $\mathrm{BN}+[\mathrm{Al}] \rightarrow \mathrm{AlN}+[\mathrm{B}]$, approaching to the equilibrium state of $\mathrm{Al}-\mathrm{B}-\mathrm{N}-\mathrm{Fe}$ system.

\section{Summary}

(1) The behavior of B atom which changes its state depending on the heating temperature before rolling, cooling rate after rolling and quenching temperature in heat treatment has been almost clarified.

(2) These results, combining with the observations by autoradiography of B atoms, quite agree with the changes of hardenability in B treated steels.

(3) The microstructure of $\mathrm{BN}$ is deduced to spherulite structure like spherical graphite.

\section{Acknowledgements}

The author wishes to thank Dr. K. Nishioka, Managing Director of Sumitomo Metal Industries, Ltd., for his permission to publish this work.

\section{REFERENCES}

1) R. A. Grange and T. M. Garvey: Trans. ASM, 37 (1946), 136.

2) P. W. Wray: Metal Progress, 60 (1951), 52.

3) C. R. Simcoe, A. B. Elsea and G. K. Manning: Trans. AIME, 203 (1955), 193.

4) G. F. Melloy, P. R. Slimmon and P. P. Podgursky: Met. Trans., 4 (1973), 2279.

5) R. Habu, M. Miyata, S. Sekino and S. Goda: Tetsu-toHagané, 60 (1974), 1470.

6) T. Kunitake, H. Ohtani and S. Watanabe: Tetsu-toHagané, 61 (1975), S217.

7) Y. Izeki, K. Saiki, K. Sakai, M. Nakamura, H. Ohtani and S. Watanabe: The Sumitomo Search, 15 (1976), 27.

8) R. S. Pease: Acta Cryst., 5 (1952), 356.

9) B. C. Woodfine and A. G. Quarrel: JISI, 195 (1960), 409.

10) B. G. Woodfine and A. G. Quarrel: JISI, 196 (1961), 297.

11) M. Ueno and T. Inoue: Trans. ISIJ, 13 (1973), 210.

12) L. S. Darken, R. P. Smith and E. M. Filler: Trans. AIME, 191 (1961), 1174.

13) Y. Omori: Trans. ISIJ, 11 (1971), 339.

14) S. R. Keown: Scand. J. Met., 2 (1973), 59.

15) H. Morrough and W. J. Williams: JISI, 155 (1947), 321.

16) R. W. Fountain and J. Chipman: Trans. AIME, 209 (1975), 1278.

17) M. Hasebe and Y. Nishizawa: J. Japan Inst. Melals, 38 (1974), 46. 